\title{
Narrative and Experience of Community as Philosophy of Culture
}

\section{(Community as Method and Principle of Thought) ${ }^{1}$}

\author{
D.A. Masolo \\ Department of Philosophy \\ University of Louisville \\ Louisville, Kentucky, U.S.A. \\ damaso01@louisville.edu OR da.masolo@louisville.edu \\ Thought and Practice: A Journal of the Philosophical Association of Kenya (PAK) \\ Premier Issue, New Series, Vol.1 No.1, June 2009, pp.43-68 \\ thoughtandpractice@uonbi.ac.ke OR thoughtandpractice@gmail.com
}

\begin{abstract}
This paper argues that the distinctive feature of African philosophising is a communitarian outlook expressed through various forms of narrative. The paper first illustrates the close relationship between narrative and community in the African cultural milieu. It then goes on to examine the way in which African academics in various fields have employed the narrative technique in their works. Next, the paper urges that through migration to European and American institutions of higher learning, African philosophers have had a significant impact on Western philosophy. Thereafter, the paper argues that while a communalistic outlook is part and parcel of African philosophising, it does not imply an insular approach to identity, but rather accommodates the fact of the dynamism of the sources of identity. Finally, the paper points out that one implication of the communalistic and narrativistic approach of African philosophy is that the dichotomy between "analytic" and "continental" philosophy, so common in the West, is not applicable to it.
\end{abstract}

\footnotetext{
${ }^{1}$ Part of this paper was originally given at a Faculty Research Forum, University of Louisville, on November 9, 2007 under the title of "From Local Idioms to Global Issues".
} 


\section{The Communitarian and Narrativistic Orientation of African Philosophising}

Many of us would hit a blank if asked to identify one thing that they believed was such a crucial and central value to how we appraise our practices that it culturally distinguishes us from most other people in the world. It was not so half-a-century ago. At that time, many leaders thought it was an obvious principle of practical reason that several types of value revolved around the idea of community. And several other important people, in the political and academic arenas alike, denied it, and even vilified those who made the claim. Today, however, things have come full circle, and a strong scepticism now hangs over the once-thought-to-be-self-evident Kantian assumption of the subject as (an) autonomous cognitive and moral agent. The waning of Kant's autonomous subject spread to other theories that grew out of him, not least John Rawls' influential theory of justice.

Although not surprising, the above developments probably still irk those who despite not having any convincing standpoints other than that they felt a threat from the overhaul of the dominant strand of European modern thought, considered the move toward communitarian thinking to be seriously at odds with the long-standing reputation of the autonomy of reason. While the view that reason, and indeed thought in general, involves an essential responsiveness to other reasons may be a new expression, and even a new direction altogether elsewhere, it has been held and expressed explicitly for decades by the theoreticians of "African socialism", among them Leopold S. Senghor, Julius K. Nyerere, and Kenneth Kaunda, to the extent that we can give credit to their political overtures-that the pivotal status of the individual that drove people's psychology and institutional goals in Europe's push to modernization was neither universal nor permanent.

The crop of philosophers whose practice emerged in the wake of these political leads handled the idea far worse than the politicians had done: the central role of the relational view of personhood was no less embodied in their work. I have suggested 
elsewhere, somehow naughtily, that even the notorious critique of ethnophilosophy by Paulin J. Hountondji was a function of the opposition between two views of the individual, namely that between, on the one hand, the individual as a transcendent Subject whose cognitive activity could be explained solely by understanding the phenomenological structure of his/her consciousness, and, on the other, the individual as a subject, yes, but rather one whose distinguishing characteristics, including developing and using reason, are always binding from without, not only in moral matters, but in every domain.

Here is a typically spontaneous testimony to what Nyerere once referred to as the attitudinal basis of socialism. In a personal communication by e-mail about his experience with village grandmothers on a visit to a bed-ridden relative in a hospital, an American friend-cum-relative wrote the following:

Today has been quiet for visitors so far. My favorites are the Danas [grandmothers]. They laugh at my Luo, and stand over the sick person and repeat, "Iwinja (in dholuo: Do you hear me)?" I will say, 'owinji, dana (In dholuo: he can hear you, grandma)', [but then] they will nod and then turn to [the sick person] and say, "Iwinja (In dholuo: Do you hear me)?" What is clear is that even conversations need a proper start. Without them, there is simply no way to begin. For [these folks], there is no such thing as a monologue. The Danas minds are deeply stuck in local modes.

Attitudes of mind are learned, both informally in the course of growing, when people are raised to learn, master, and be able to apply to their lives the principles of practical reason, and formally when they are taught to reflect on what it is about those principles that warrant them to be regarded the way they are. For example, some people grow up knowing that it may not be regarded polite to go visit anyone, not even a parent or brother in another village or part of the city without checking with them if it is acceptable to them. In another part of the world, failure to connect with, and especially to visit relatives and friends from time to time may be regarded as lack of social virtues such as taking seriously and manifesting through visits or other symbolic forms, that one cares deeply about friends and kin. Asked why they live by those principles, those who inhabit either framework may say simply that "it is the right thing to do", and so a right thinking person simply does it because it is expected. But you and I may debate forever about what it is exactly that makes such expected behavior right, thus seeking not only to justify, but also to see ways in which practical reason can be controlled and reproduced under different circumstances. For the rural women folk in the correspondence, their connections with others in the social world 
jump to life in communication with those they care about. Not even death can be regarded as an occurrence that takes place to persons in the depth and privacy of their bodies. It would be unimaginable for them that there still is a relationship between them and the sick person if it cannot be defined by a direct communicative engagement with him, for, in their view, personhood abides in the capacity to communicate.

Despite the controversies, the idea and role of community as the axiomatic principle around which experience is organized and evaluated was hardly ever in question which is why it has re-emerged in major texts of contemporary African philosophy, namely in the metaphysical, epistemological, and moral analyses, in autobiographies, in the village palavers, and in other forms of narrative which, in some instances, now present the contemporary African philosopher as in part the present-day griot, narrating his/her philosophies to the rest of the world in one or more of those poetic genres with roots deeply planted in the indigenous methods. The practice awakens several filiations with those indigenous presentation styles, even as it also connects with the more recent literary concept of narratology as an interpretive form for analyzing and understanding literary productions. First, plotting theoretical presentations through narratives is a well-known medium of oral cultures, and lies at the heart of African traditions. Present-day African philosophers appropriate and use it in very new global contexts. Second, because the narrative technique in the history of Western thought can be traced back to Aristotle's Poetics. There, the Greek philosopher tells us that as an art, different types of poetry are distinguished by how they variously mix and combine rhythm, language, and harmony to attain their specific ends.

\section{Narrative in African Academic Discourse}

African novelists were the first to make the narrativistic connection with the tradition of story-telling, widely using the short story genre to make a variety of representational transition into contemporary literature, and with it, transiting from the oral to the written word. The plot is far more complex this time than it was for the village story-teller. First, while revealing the hearts and minds of the original 
narrators and listeners, the stories also aimed at availing their objectives to broader audiences, making connections with worlds far beyond. Indeed, according to Ricoeur (1984), narratives (récits) both shape our experience of reality as much as they bring us to terms with temporality. But one might ask, "What reality, and in what ways do African narrators I have in mind think we should think of the reality they tell us about in temporal terms?" In other words, how do the narratives remedy the communityindividual controversy?

Aristotle says in the Poetics to those who read him that we execute the plots in the stories we tell either by means of our own anecdotal autobiographies, or by use of other agents or characters. We can also recite our stories by using a combination of both strategies. Aristotle says:

The objects the imitator represents are actions, with agents who are necessarily either good men or bad - the diversities of human character being nearly always derivative from this primary distinction, since it is by badness and excellence [that] men differ in character. It follows, therefore, that the agents represented must be either above our own level of goodness, or beneath it, or just such as we are ... (Aristotle 1984, 2317).

And in Chapter 3 he continues:

Given both the same means and the same kind of object for imitation, one may either speak at one moment in narrative and at another in an assumed character... or one may remain the same throughout, without any change; or the imitators may represent the whole story dramatically, as though they were actually doing the things described... the differences in the imitation of these arts come under three heads, their means, their objects, and their manner (Aristotle 1984, 2317).

Story lines in narratives take the form of either conversational anecdotes, or narratives of personal experiences, or some other type of tales. With variation, African philosophers, like the griots of history, have been delivering their subject matter in this customary style, making philosophical deliberation both interactively engaging as it is challenging in its nuances. In addition to style, and more specific to Africans' practice of the subject, this delivery also introduces another dimension to the "poetics", namely the view that thinking is a relational process that takes place meaningfully only in a communal context. As I noted at the beginning, not only is reasoning a response to (other) reasons, it is also the act by which we commit ourselves to norms, or, more precisely to specific norms among others. Without delving into what I have said more substantively elsewhere, I want to argue that although more evidently in some cases than in others, communitarianism is all over African texts, either as an axiom that informs and directs Africans' theoretical 
practice in the human and social sciences, or as a topic of discourse and analysis, and that this specific communitarian framework has opened doors to alternative ways of looking at philosophical issues, both new and old.

\section{The Impact of African Intellectual Migrations}

As a result of recent global relocations, African philosophers have brought their communitarian approach to knowledge production to Western academies and to their organs of dissemination. In doing so, African philosophers have demonstrated the human "imitation" of the natural force of $\mathrm{Ombasa}^{2}$, the traveling plant. They say in my Luo language that "Dhano chal ombasa: k'ochiek bu otwo to omuoch bu kothe kir-re bu twi kanmoro nono (humans are like the Ombasa, the traveling plant (Kokwaro 1972, 71), which spreads when its mature, and its dry pod bursts open, thus freeing and hurling its ripen seed across territory to new grounds where it sinks and spreads its root)". Known by their legendary historical migrations, the Luo know the dynamism and complexity that human mobility brings to knowledge, belief, and customary practice. ${ }^{3}$

Intellectual migration and transplantation of thought is not unique to either Africans nor to the recent episodes of political unrest and conflict elsewhere. From antiquity, various local traditions of thought have been transformed either by the influx of thinkers from abroad, or by locals returning home from foreign excursions. Ancient Athens, the Upanisads in classical Hinduism, middle- ages thought in West Africa, early modern-times school in Ethiopia, and the Ghanaian Wilhelm Anton Amo's return from Germany, are all examples that spread across the ages. And more recently, for instance, the current and predominant American philosophical landscape is itself a fruit of transformations occasioned by travels and migrations such as those which now have brought the variety and influence of African philosophy to the

\footnotetext{
2 Known in technical botanical terms as "Tylosema fassoglensis (Caesalpiniaceae)" - see entry in Kokwaro, John O. 1972. Luo - English Botanical Dictionary. Nairobi: East African Publishing House, p.71.

${ }^{3}$ Luo migration and the encounter it bore on them with other cultures is vividly captured by Grace Ogot in her novel, The Promised Land, Nairobi: Heinemann Educational Publishers, 1966, and is also the theme of Bethwell A. Ogot's History of the Southern Luo, Vol. 1: Migration and Settlement 1500 1900, Nairobi: East African Publishing House, 1967.
} 
American academic scene. The travels of W. E. B. Dubois in Europe brought the influence of Herder's romanticism to bear upon how he subsequently viewed the idea and possibility of cultural autonomy for African Americans. W. V. O. Quine's travels to the pre-WW II Europe, especially to England, Germany, and Austria, put an indelible mark on American philosophy, one which, since around 1932, made analytic philosophy the main current of thought. Also, the migrations of many eurocontinental philosophers, especially those from Germany in the period immediately preceding and lasting long after WW II, brought to the Americas the neo-Marxist dimension of the Frankfurt School out of which grew and spread the social-critical dimension of doing philosophy that has since extended its influence far beyond the conventional confines of philosophy.

Human mobility, like the one witnessed recently, and even currently as a result of the new international assertions of freedom, represents an important dimension of how knowledge migrates, in the process transforming and getting transformed by the local knowledge and other cultural forces in the new settlements. Indeed, we humans are like the Ombasa plant. It is, therefore, a matter of irony that while acknowledging and speaking from a migratory standpoint, defenders of a "pure" Afrocentric civilization which, in their view, was located in ancient Egypt, claim only a one-way flow of knowledge - other Mediterranean people taking from Egypt even as Egyptians mingled with their regional neighbors.

The migration of African intellectuals to both Europe and North America is the most recent wave, and continues to occur alongside other migrations, especially from countries and nations in the former Eastern European bloc. It is arguably safe to claim with some degree of probability that the entry of African philosophers into Western academic institutions generally, and those in the United States particularly, has started to change the presentation of issues in the discipline in ways that are more significant than just the migrants' own physical and social presence and appearance. The fact that an African-descended philosopher is president of the Eastern division of the American Philosophical Association is a mark of this growing visibility of Africans in the field. Other foreign-born philosophers have preceded him in this position. About twentyfive years ago, the English translation of Paulin Hountondji's book, African Philosophy: Myth and Reality (1983) was published in London, and became a huge 
success, not in the United Kingdom, but in the United States where the field of African studies was taking a new turn in the hands of African scholars themselves, in bringing there the then hardly-recognized idea of African philosophy to the Western academy, thanks to publishers already well established in the area of African Studies and willing to add this new dimension of African systems of thought to their existing series.

\section{Conceptualising Community}

Within the field of African studies itself, and more specifically among some African scholars, Paulin Hountondji's work, beginning with his first widely-known essay of 1977, triggered a kind of debate whose gist has tended to fade, or not show up at all, outside the circle of African scholars themselves. ${ }^{4}$ Hountondji (1983 \& 1992) offered a fierce critique of the idea of ethnophilosophy, which had first been broached on the occasion of the publication of Placid Tempels' La philosophie bantoue (1945). Hountondji frames his objection to the idea of an ethnophilosophy in terms of his view of the location of theory within the structure of consciousness, thus camouflaging the real issue at the heart of the debate, and distorting the nature of the object of the debate between him and his critics.

My claim here is that the real issue, namely the idea of community, considered to be central to African thinking, and which, in the eyes of his critics, Hountondji was opposing, has only recently progressively become clearer. In retrospect, the controversy was probably unnecessary, because each side addressed a different aspect of the matter. More specifically, Hountondji was astonished by the embrace, on the part of otherwise well informed African scholars and philosophers in particular, of the then common descriptive phrases like "the philosophy of the Bantu", or of whichever other community to which whole thought systems, and sometimes even theoretical

\footnotetext{
${ }^{4}$ Hountondji's critique of the proposal of a "passive thought", which he thought to be embedded in the idea of ethnophilosophy, probably goes as far back as his encounter with the texts in that school of thought in contemporary African philosophy, but, in his writings, is probably traceable to the essay, "Sagesse africaine et philosophie moderne." In African Humanism-Scandinavian Culture: A Dialogue. Edited by Torben Lundbaek, pp. 187 - 97. Copenhagen, DANIDA. A more widely-circulated version was published as "Remarques sur la philosophie africaine contemporaine." In Diog Пne, No. 71, 1970, pp. $120-40$.
} 
positions, were being habitually attributed. This attribution was, in his view, wrong on account of the location of theory within the structure of consciousness, something he believed to have been compellingly explained by the German philosopher Husserl, and which identified theory generally, and philosophy in particular, with a scientific endeavor, part of reflective consciousness.

Hountondji had read Husserl rather well under the guidance of Paul Ricoeur. Hence, for him, the claim that philosophy could be passive and anonymous, as suggested by the idea of "ethnophilosophy", was simply a misnomer. At that point, the matter should have been closed, because he was right. And more importantly, that position, stated as I have just done, said nothing about, nor was it incompatible with, the idea of community as an oxiomatic lens through which to look at the world in search of viable grounds for identifying and defending any type of theory such as the nature truth, or an aesthetic norm, or a theory of how people ought to behave. Hountondji's critics see in his insistence on the idea of philosophy as a science a rejection of the communitarian idea in favor of individualism, elitism, among other characteristics always and mistakenly associated with the European thought system.

Be that as it may, the idea of community pervades African philosophical texts, those of Hountondji included, at least in his more recent and relatively softened stance. To see the assumption of community at the base of African philosophy as its truly distinguishing mark, one has to start with its narrativistic style which has emerged as a sharp contrast to the formalistic style of a significant setting of Western philosophy, namely its American brand with which some of us have become familiar. If narrative is a relational act, or evokes it as a condition, then it may now emerge at least for a reader who seeks to make sense of Hountondji's critics' attention on the issue of the non-relational subject rather than on his notion of theory that was so pertinent to his critique of ethnophilosophy. Finally Hountondji saw the point and, as if to respond by situating the subject back in the middle of a conversation, explains in his recent autobiography contra-ethnophilosophiae, The Struggle for Meaning (Hountondji 2002) in a manner that hopefully placates his critics.

If The Struggle for Meaning re-positions the Subject within a community of dialoguers, it also questions how community is to be defined, and what Subjects are 
supposed to regard as their community in the contemporary contexts of travels and migrations in which Subjects, like the Ombasa seed described above, are catapulted across many cultural boundaries into territories far away from that of their original roots, thus enabling the mind with stimulations different in their specificities. ${ }^{5}$ The question, which can be asked about the literal Ombasa but also about its metaphorical human analogue, is, then, is a migrated Ombasa plant any less of its kind simply by virtue of its migration? Hountondji shares this interrogation of community viewed as a fixed and unchanging entity with Kwame Anthony Appiah as can be remembered from his In My Father's House (1992), which is sometimes billed as the triumph of liberalism in contemporary African thought. His ideas of community have been addressed more directly in Cosmopolitanism: Ethics in a World of Strangers (2006).

Common to both Hountondji and Appiah is the problem of how to conceptualize community in both its structural, historical perspectives and contexts. Historically, the idea starts right with the "Préface" of In My Father's House, even if the full account of the matter is given only in the "Epilogue". The narratives can be put in question forms as follows: what should the world look like for the contemporary African who is cosmopolitan by virtue of his/her globe-trotting and international connections, most likely college-educated, perhaps also converted - probably to Christianity - and whose new social world, by the strength of the above, has now extended_far beyond the boundaries of the original locative roots of the clan system? And what if, again by the strength of the geo-social and cultural expansiveness caused by both travel and choices of affiliation, the genealogy of this contemporary African in fact now derives from, just as much as it points to, similar world wanderings from which have come a complicated social world that no longer traces itself by only a single lineage system, but rather by mingling different lineage types such as matriarchy with patriarchy, which we were once told to be mutually exclusive?

\footnotetext{
${ }^{5}$ Arguing for the universality of cultures on account of this transferability or migratory characteristic of mind, Wiredu argues - in Cultural Universals and Particulars - that it is form, and not the specifics of cultural contents, that define our humanity. However, real human life is lived in the realm of specifics, albeit without transforming such specific contents of culture into traps of relativism.
} 


\section{Changing Perspectives of Identity}

The question above camouflages my intention here, namely, to call for a reflection on identities at multiple levels, local, regional, and global, because it evokes a reconsideration of the factors which not only inform how we think of our identities across different boundaries which we are likely to cross in the course of our cosmopolitan migrations, but also to enable us to reflect more carefully on how we can go so terribly wrong when we think of the social world in terms of essentializing differences between the groups that populate it, not only in their supposedly fixed metaphysical constitutions, such as race or ethnicity, but also that these assumed foundational differences lead to other differences, especially in cultural beliefs and practices which we proceed to argue, however wrongly, to be warranting of differential treatment of people who are dissimilar in those terms.

We have painfully learned from recent history that in situations where members of one group think of those in other groups to be essentially distinct from them, it can become easy to consider them as dispensable. Stories of identity-based conflicts suggest that they begin when those in one group regard others as unjustified obstacles to the attainment of what is their natural right, and so they can go ahead and eliminate them. Based on perceptions of power and advantage, collective conflicts occur when one group perceives another as an obstacle to the realization of the ends that it believes to belong to its own exclusive rights to a specific type or set of claims. The reasoning proceeds as follows: Fairness applies only to the treatment in relevant cases of those who are similar. So whoever is not similar to me in the basic or essential characteristics of identity does not deserve my fair consideration. If they are not like us, then they most likely do not matter where our interests are concerned. Rather, they must be a problem to be solved. In other words, the fatality of the Other as a path or opening to a desired end for oneself becomes an easy ideology.

It is no wonder, then, for example, that in the 1994 Rwandaise genocide, or in those other eruptions of ethnic cleansing in Eastern Europe, those in the attack often referred to their victims as something far less than themselves, and they took their 
own identity to be the measure of humanity. In the Rwanda episode, the attackers were reported to refer to their victims as "cockroaches" rather than as other people with rights that are similar to those of everyone else, including their attackers. But the train of thought that isolates people into "essentially different groups" is wrong on one major account: human identities are not metaphysically fixed, and hence do not bare any differences upon which one can validly justify a moral scheme, especially such a serious one as deciding who does and who does not deserve to live. Contrary to the false idea acquired from the remnants of modern European thought transported across the globe by colonial forces of "national groups" as homogeneously constituted and hence crucially different from each other, communities in African knowledge and practice were understood to be historically blended either as a result of travels and the ensuing deliberate strategic choices in response to different human circumstances, or by reason of customary distribution of power and control within specific social systems. ${ }^{6}$ In fact, many African peoples have never been "modern" in the sense of the homogeneity imposed upon them by Victorian anthropology and other forms of colonial knowledge.

My point against the background of genocides which result from the political cockroachization or other forms of reducing others to "beings-less-than-human" is that if the fluidity of community was never clear enough before, because those who preached modernity to their African subjects led them into thinking of community as fixed, then contemporary mobility should disprove the underlying false metaphysics by unveiling the basic migratory characteristic of the human condition. In my own lineage of birth, for example, I can count several lines of descent that point to at least three different ethnic origins. In my own family today, there are at least two more, all scattered over the wide Eastern African region. In historical fact, the trek brought

\footnotetext{
${ }^{6}$ The debate among the Basonga people over my maternal grandfather Oloo Wanyande's lineage, and therefore over the legitimacy of the jurisdiction of his chieftainship over the self-declared Bantu clans of Bunyala is a good example of how claims of social identity are often the function of or overlap with political and territorial claims. In this example, the debate was either driven by, or was extended into debating the ethnic boundary between the Bantu Luhya of which the Bunyala clans in question were part, and the dominant Nilotic Luo, the latest migrants into Western Kenya shores of Lake Lolwe (later named Lake Victoria by the British). On the other hand, a good example of deliberate engineering of family identity is given by Nkiru Nzegwu in her critique of patriarchy against what she terms Igbo women's control of their sexuality and, consequently, their own and Igbo society's idea of lineage as biologically and socially heterogeneous even within same households. See her Family Matters: Feminist Concepts in African Philosophy of Culture, Albany, NY, State University of New York Press, 2006.
} 
them to their present settlements through several centuries during which they most probably endured internal and external conflicts, break-ups, and therefore constant losses and gains in population and social make-up. Legend tells us of numerous such incidents. Just look at the variations in a people's language!

I learned from Philip Ochieng', the renowned Kenyan journalist, from Duncan OkothOkombo, the polished linguist, and from Elisha Steven Atieno-Odhiambo, the erstwhile, now sadly only late Kenyan historian, that identity claims are not based on blood but on gradually contemplated choices of what is regarded to be politically and socio-culturally prudent, viable and beneficial. Identity claims are strategies for adaptation to social, cultural, economic, and political conditions. They hang on historically encountered realities. Hence, who knows, and what does it matter, that my clan is both "Kaugagi" and "Abukaki" and, on that strength, both Nilotic and Bantu at the same time? Or, to cite other similarly mixed or crossed-over clans, that Asembo is partly Teso, and Sakwa partly Maragoli, or that Suba is partly Ganda?

\section{Broadening the narrative}

The production of knowledge is not, and should not be, limited to the discernment of our collective identities. It ought to expend the horizons of Africans' own poetics. Jean-Godefroy Bidima, the young Cameroonian philosopher, puts it well:

Nous avons donc besoin, en tant qu' $\square$ tres historiques, de nous raconter des histoires sur le vrai, le beau, le bien, l'identité, l'alterité, l'absolu, la valeur, et la finalité. Nous avons aussi besoin, en tant que philosophes, d'afficher la gravité de notre fonction et de notre interrogation en faisant comme si nos récits sur le beau, le vrai, le bien n'étaient pas les $m \square m e s$ histoires que les humaines se racontent partout pour apaiser d'une part l'inconsistance et l'incompréhension que produit leur utilisation de langage, et d'autre part pour ressouder leur tissu symbolique! (Bidima 2007).

(We need, as historical beings, to narrate to ourselves our own accounts of the truth, aesthetic form, the good, and of identity, otherness, the absolute, and destiny. But we also need, as philosophers, to make known how crucial our role and our interrogations of reality are, just like people everywhere else do, by explaining and making sense of our languages regarding the listed issues, and by demonstrating the symbolic ramifications and interconnections the concepts have for our experiences.)

In Bidima's view, the responsibility of unveiling African knowledge, such as accounts of the principles of truth, of moral good, and of their aesthetic theories, namely their experiential inscriptions on the world, lies with African philosophers. But, above all, 
these accounts matter only when they are endogenous, or, when acquired by virtue of travels, that they are indigenized and transformed into idioms of local discourse. So when Appiah writes in the "Preface" to In My Father's House that "This book is dedicated to nine children - a boy born in Botswana, of Anglo-Ghanaian parents; his brothers, born in Norway and in Ghana...." (Appiah:1996, viii) and goes on to sketch a social map that extends from the southern-most to the northern-most points of the globe, and from the depths of so contrasting religious belief systems, I can relate to these multiple origins of identity. His aim is not merely to repeat what may be so familiar to most communities. After all, except for an occasional and romantic reminder of one's distant history, the stories would be of little worth as threads for the construction and narration of selfhood.

For Appiah, on the other hand, as for most of us for whom one's social map informs many choices for any given person's reverence to others depending on whether he/she is vertically or horizontally related to them, these things matter. What does not matter, because the idea and historicity of this kind of selfhood and community-building precludes it, is the view that communities are homogeneous in any form or shape. It is therefore sufficient to say that Appiah's $(1996,22)$ point is that these complex building blocks of genealogy should not be lost to us. As he says elsewhere in a remark he attributes to his late father, there is no use having roots if one cannot take them with him/her in these wanderings (Appiah 1996, 22). Even more significant, I believe, is the unspoken call there that one should not forget, nor should he/she remember only when convenient, that we all have these complex origins that re-direct our gaze to different points of the global compass. When we do, and rather mistakenly so, the likelihood of viewing others, depending on how we choose to define ourselves, as those toward whom we are ready to disregard any obligation to fairness on no grounds other than that they are not our kin, becomes greater, and hence the likelihood of any form of discrimination which may include violent attacks and genocide, is equally greatly heightened.

On the contrary, when we think of ourselves, and of community and culture, along the lines of being connected to others far beyond the location of any one of our multiple genealogies, Appiah says, "one is bound to be formed morally, aesthetically, politically as well as religiously by the range of lives one has known" (Appiah 1992, 
p.ix). The point is not to forget any of them, because they all have validly contributed to making us who we claim to be. Humans are like the proverbial Ombasa plant. $^{7}$

The idea that we are absorbed by and participate in multiple communities whose evolution and functional realities are shaped by the strength of our travels is probably what has recently been expounded by Hountondji as well in Cambats pour le sens (Struggle for Meaning) (1997) as a response to earlier accusations of espousing subjective atomism as the valid basis for grounding cognitive and moral experience, judgment and responsibility which, in the eyes of his critics, come with framing all knowledge, including philosophy, as science. It is my considered view, which I cannot be sure Hountondji himself would recognize or agree with as part of his thinking, that the unfairness of such accusation emanated from a restricted view of community. In Struggle for Meaning, Hountondji defensively narrates how the seeds of his intellectual life began with and included a seminal and strong Beninois formation before extending, by virtue of travel, to the corridors of the Lycée Henri IV and to the Sorbonne where, through the mediation of his eminent teachers such as Paul Ricoeur and Jacques Derrida, he encountered Husserl and his idea of philosophy conceived as a strict science, and how this became instrumental to scrambling and reconstructing the African knowledge-base in its historical context. This discovery led Hountondji, in his own words, "to a critique of ethnoscience in general, understood as a clever way of freezing traditional systems of knowledge by emptying them of their dynamism, of their power to transcend their limitations, their autonomous capacity for enrichment and improvement" (Conteh-Morgan 2002, p.xix).

As explained earlier, the gist of Appiah's discussion of the possible effects of cultural exclusivity finds full treatment only in the "Epilogue" to the book. There, in a well-

\footnotetext{
${ }^{7}$ Because of this, our value judgements can remain strongly community- driven while suggesting two identifiable approaches as follows: one, that the liberal golden rule of morality is either universal by virtue of this global idea of community, which is Appiah's argument, or, two, that a better moral theory should be one that views the need for morality and the basis of moral judgement as consequences of the relational (communalistic) nature of human life and experience, and therefore as emanating from an unbounded sense of respect for others on the strength of the principle of mutuality because we identify with them in both real and imagined ways through the expansion of our social world. The latter, I believe, is how Wiredu approaches the matter. See Cultural Universals and Particulars, Bloomington, Indiana University Press, 1996, p. 29. Community is the basis of the principle of sympathetic impartiality which, in Wiredu's view, pulls Kant's principle, the categorical imperative, back from the mechanistically atomic (metaphysical) apparatus of the Subject to the communal or relational human condition where morality belongs.
} 
executed narrative, he tells of the conflict that inevitably erupts as a result of two epistemic stances, one that assumes an unchanging core of the itinerary of tradition on the one hand, and the other that draws from perspectives of a world whose exigencies have shifted and wich regards traditional reason and its premises as needing to be freed from the freeze of fixed custom by both restructuring and reformulation. It is Aimé Césaire $(1953,31)$ who opens his Discourse on Colonialism with the statements that "A civilization that proves incapable of solving the problems it creates is a decadent civilization. A civilization that chooses to close its eyes to its most crucial problems is a stricken civilization. But more significant, a civilization that uses its principles for trickery and deceit is a dying civilization." Césaire was lashing out at the idea of what he contemptuously refers to as "the so-called European civilization". But such failures could occur anywhere and to any system of culture, African ones included, that provides norms on the basis of which those who live under or within it conduct their lives. In this (Césairean) sense, the problem that both Hountondji and Appiah point at in their respective and very different styles is one of history: the failure of many African intellectuals and leaders of different ranks to sufficiently transform their perceptions and conceptions of the world to adjust to changed times.

On the one hand, Hountondji, informed also by Gaston Bachelard's idea of "epistemological break" or rupture, endeavors to point out that contemporary Africans cannot ignore the achievements of contemporary scientific findings or technological solutions to problems by insisting, as ethnophilosophers were trying to do, on relying on the claims of a foundational and unchanging view of mind, or on a worldview driven by an essentialist and fixed framework. This view, which underscores the idea that the objects of knowledge, whether they are of scientific investigation or of the practical principles for guiding daily lives, are not found but instead are made ${ }^{8}$ by means of careful deliberation, now seemed to expose a contradiction within the ethnophilosophical discourse itself - one that aims at asserting the sociality of knowledge production, yet, because it was pressured by a colonial intervention from

\footnotetext{
${ }^{8}$ There is a debt here to Bachelard. See, for example, Bachelard's La philosophie du non: essai d'une philosophie du nouvel esprit scientifique, Presses Universitaires du France, 1940 ( Eng. trans. G.C. Waterston, The Philosophy of No: A Philosophy of the New Scientific Mind, New York, Orion Press, 1968). By interpreting modern science as a kind of reformulation of Kant's key concepts key concepts of the categories of the empirical world and of human reason, Bachelard insisted that science occurred in history not in a linear and uninterrupted manner, but rather in breaks or ruptures.
} 
which it sought to extricate itself, slipped back into an ideologically stagnant stance because it placed a premium on re-asserting the foundations of its autonomy.

In other words, Hountondji now appears to be saying that all along it was he who was adhering to the idea of a communal production of knowledge by seeking to engage others in constructive dialogue for the benefit of African societies. By rejecting the passivity of the ethnophilosophers, he was calling for the re-organization of knowledge by appealing to the recognition of the changed historical circumstance of African societies, a call he saw to be critical to the endogenous production of knowledge. Knowledge, in his view, is constituted through dialogue in communal contexts, whether it is through the informal narratives and contestations of culture as we observe to take place in search of those principles of practical reason; those that address either questions about how we decide what to do in specific circumstances of life, or questions about what states of affairs are worth realizing, and what objectives are worth achieving; or in the formal or theoretical analyses of what it is that makes a particular decision the best, or a specific objective the best to achieve. Also, for any given historical and social condition, the growth of knowledge does not have to wait for sparks or leaps to occur within to be meaningfully indigenous; rather, it can, and should, judiciously incorporate and indigenize in a way that modifies for local applicability the relevant components considered either to be reasonable or to have worked elsewhere.

\section{The methods: mixing narratives with analysis}

We are used to viewing and explaining the practice of African philosophy by fitting it into the intellectual stamp cut out of the Euro-American configuration that gave its post-colonial shape, such that African philosophy, like its Euro-American ancestor, is also only either "analytic" or "continental", as is largely also indicated by the boundaries and barriers of European language use. However, by the practice of fusion, the use of narrative, as the communalistic method, defies and transcends the

\footnotetext{
${ }^{9}$ See, for example, Barry Hallen's elaborate analysis and discussion of the analytic approach in African philosophy - African Philosophy: The Analytic Approach, Trenton, NJ, and Asmara, Eritrea, African World Press, 2006.
} 
analytic-continental demarcation, thus indicating, even to the Euro-American field itself, that these two intellectual heritages do not have to be regarded by their heirs as inimically unbridgeable. ${ }^{10}$

The question, then, is: how are African philosophers applying this "communal production of knowledge" to their practice of philosophy? Or, put differently, how are they using the model of narrativistic communal engagement and experience to articulate or discuss specific philosophical issues? The dominant methods of exposing philosophical explanations in the Anglo-American and European world tend to be two: either the grand interpretive descriptions of the world, or the micro clarifications of the intentions or contents of the mind which the exposers want to exactly determine by comparing and contrasting examples in both language and practice where such intentions, or meanings as they are often called, seem to be the object or part of a series of objects (of thought). Let us consider an example of the first style, rather randomly, from any exemplifying text. Here is one:

Enfeeblement of the nerves expresses itself in the fact that impressions that should merely have the degree of strength sufficient to make them data for the understanding reach that higher degree at which they move the will....Finally, the cognizance that I have of my will, although it is immediate, is still inseparable from that of my body....(Schopenhauer,2008, 138139).

The analytic brand, on the other hand, can be exemplified as follows, again, just randomly selected:

I described utilitarianism as a saying that an action should be performed only if it promotes the greatest happiness or the greatest preference satisfaction. However, there is an ambiguity here. Are we evaluating kinds of actions, or individual actions, one by one? That is, are we to use utilitarian considerations to decide what general rules to follow, or are we to apply these considerations each time a specific act is at issue?.....(See Sober, 1995, 452)

Although these two examples do not stand for all the common features which characterize the two respective philosophical styles in Euro-American practice thereof, they indicate the monological style of the thinker - as a person who stands alone with only his/her mental representation of reality to describe in general interpretive terms, as in the first example, or by trying to determine its mental

\footnotetext{
${ }^{10}$ In their joint essay, "The Impact of African Studies on Philosophy". Bates, Robert, V.Y. Mudimbe, and Jean O'Barr eds. Africa and the Disciplines: The Contributions of Research in Africa to the Social Sciences and Humanities. Chicago: University of Chicago Press, 1993, pp.113 - 138, V.Y. Mudimbe and Kwame Anthony Appiah have summed up the African path to the resolution of such antinomy in Euro-American philosophical tradition since Frege's influence positioned itself methodically against that of Husserl, or Hegel before him.
} 
intentions as conveyed by language, as in the second. Now let me give another example which I think deviates from such a monological stand. This too is a randomly chosen example. It goes like this:

Gracing a wall of my father's living-room was a vibrant, evocative, and prepossessing work of art depicting a forest inhabited by elephants and men. Early childhood lessons on savoir-faire, tolerance, and mutual respect were taught through this drawing....

This vivid imagery captured the attention of visitors to our compound. And there were many visitors. My father was a popular figure....(See Wingo 2004, 425)

And here is another one:

....Dressed in white cotton to reflect the sanctity and spiritual state of her person, Omu Nwagboka sits on the dais in her palace, surrounded by women councilors...As Omu, she is the watchdog for the community and Ikporo Onitsha....An Omu is not related to, or accountable to, the Obi, the male monarch... [This woman authority is about to oversee or mediate an intercultural debate on the issue of women's equality with men folk.] (See Nzegwu 2006, 161)

In contrast to our first two examples, the latter two have the following relational features:

- They are both set in communal contexts by way of being cast in either narrativistic or dialogical formats or both.

- They have characters who are described as drawn together around a symbol of communal significance or authority.

- They are set around and discuss succinct theoretical issues which they introduce and explicate by the use of stories and tales.

- While the dialogues themselves invariably incorporate either analytic schemes or sometimes lengthy accounts, the narratives help to underscore the idea of the inter-subjective or communal production of knowledge.

Sometimes, like one reads in the Dogon and Bamana texts, complex figurative or symbolic forms are used as stand-ins for concepts in use in the exposé. The thinker becomes a narrator, or vice versa. ${ }^{11}$ Thus, whether they are about procedural propriety and (a liberal) recognition of the voices of all those involved in and touched by family events, or the impromptu dialogue between Ogwang' and a group of those

\footnotetext{
${ }^{11}$ I am reminded here of the epic story, which is a film, Taafe Fanga (translated as 'Skirt Power'), in which a Bamana griot tells of common misconceptions of gender equality, and the resistance by a once-dominant and secrecy prone patriarchal system of the group in the historical and difficult path toward a system of mutual gender recognition and respect on the basis of 'equality in difference'.
} 
he calls moral hypocrites ${ }^{12}$, narratives are used to frame issues of interesting philosophical inquiry (or argument) such as the defense of the importance and relevance of liberalism as a public ethic, the concept of art, or the definition of a morally good life. Again, whether Ogwang's or another person's, the narratives often take either the biographical or autobiographical form, in which the narrator takes the witness stand to represent matters as a participant in a discourse whose significance supersedes a monologue. For knowledge is not a monologue of single actor acts. This, I contend, is new to the Western academic discourse, and makes philosophical discussions interesting on at least two levels - of the theories they articulate, and of the culturally rich and informative stories they tell.

African philosophers have carried and brought their stylistic roots, the narrativistic form, with them into the Western discourse generally, and particularly into its academic discourse where the idea of community has spread. Two things can be related to this phenomenon. First, it re-inserts the involvement of persons and human interests into the dynamics of knowledge production in a novel manner by underscoring its inter-subjective character. It would then follow that the standards of judgment of what is aesthetically pleasing, what is morally good, what is socially attainable or acceptable, or what is epistemologically true are, or can only be the function of the discursive and inter-subjective enterprise that alone defines what it means to be human.

If we grant, then, that the social world is always fluid and unfixed, and given stability only by cultural acts of human choice as the complex Dogon literature tells, then who,

\footnotetext{
${ }^{12}$ Ogwang' is a figure that sometimes is real, and quite fictitious at others when his image is evoked to represent a local voice. But in this instance he is real - he narrates his confrontation with a group of Christians returning from Church while he is on his way home from an overnight cultural musical performance. Those in the group tell him that he is condemned to hell upon death because, according to their new Christian teachings, his performances are associated with "evil" because they morally corrupt society. People who commit evil acts go to hell. In his lyrical response, Ogwang' seeks to know what it is about this new moral framework that makes it superior to the moral order of his own people whose maxims he has followed to his best ability. On these matters, he observes, neither the so-called gods, nor the so-called satans give him satisfactory explanations, and concludes that if by heaven is meant moral approval, then he seeks to know why suddenly (which is his idea of the abrupt appearance of Christianity) a performance that only makes people happy and celebrates their good deeds now becomes a ground for condemnation. He concludes that when judged by his own people's maxims a morally good life, even the Christian Satan would be bewildered by what an insurpassable performer he is that makes everyone happy, including Satan himself who would be knocked off by his skills. In conclusion, Ogwang' says that he knows of no moral order that does not reflect an actor's awareness of those social-moral standards that make life good for persons in their societies.
} 
or what, do I consider myself to be? And how do I function as an agent of epistemological, moral, or aesthetic judgments in such a relationally construed world? As a reader of this piece this far, you probably suspect already the references that I would want to make here ${ }^{13}$ to illustrate how some African philosophers have applied these answers to some metaphysical, epistemological, ethical, political, and aesthetic positions within the corpus of African philosophical text. Whether it is about the scientific stories, or those intensely contentious moral ones, those about aesthetic forms, or about how we influence public policy by practicing our civil rights, the language and practices of inquiry are only guides to a shared approach to those deliberations and decisions on matters which affect everyone.

The idea of a shared approach to knowledge is one that addresses everyone. For instance, the idea of juok as a moral disposition that calls for responsible conduct might be an idiom local to speakers of the Luo language in Eastern Africa; but its object is by no means restricted, or restrictable, to the specifics of the specific conduct of persons within the social and geographical environment of the Luo as a community. Indeed, in a world that today is no longer exactly as it was for a person in such limited circumstances, the playing field from which a person became a subject of moral characterization has also changed, expanding correspondingly with his/her world of sojourn. In the local Luo environs, a jajuok was an agent whose social mischief was limited to roaming and frightening people in the obscurity of night, usually his/her own relatives and neighbors in adjoining homesteads to his/her own. Under new circumstances where the formerly local jajuok has been able to travel away from home, and where he/she suddenly realizes that the conceptual extension of

\footnotetext{
${ }^{13}$ Among the so many texts out there on diverse communitarian issues, the following serve only as indicative. For metaphysical, epistemological, and ethical implications, see Wiredu, Kwasi, Philosophy and an African Culture, London, Cambridge University Press, 1980, and Cultural Universals and Particulars, Bloomington, Indiana University Press, 1996; on a good discussion of African communitarianism, see, for example, Gyekye, Kwame, Tradition and Modernity, Philosophical Reflection on the African Experience, Philadelphia, Temple University Press, 1997; for social identities of persons and heir implication on ethics, see, for example, Appiah, Kwame A., The Ethics of Identity, Princeton, NJ, Princeton University Press, 2005, and Cosmopolitanism: Ethics in a World of Strangers, New York, W. W. Norton and Co. Publishers, 2006; in aesthetics, see Wingo, Ajume, "African Art and the Aesthetics of Hiding and Revealing”. In British Journal of Aesthetics, Vol. 38, No.1, July 1998, pp. 277-291, "The Joy of Living Together: Towards an Appreciation of Laughter". In Journal of Political Philosophy, Vol. 18, No. 2, 2005, etc.; Wiredu, Kwasi 1980; 1996; 2004, and several others; and in feminism, see Nzegwu, Nkiru U., Family Matters, Feminist Concepts in African Philosophy of Culture, Albany, NY, State University of New York (SUNY) Press, 2006.
} 
"a mischievous act" covers a globally extendable field of similar acts, the characterization calls for an expanding revision.

So, who is a jajuok? As I have said elsewhere ${ }^{14}$, contrary to the once-popular tendency to explain the term in metaphysical terms, a more complete consideration of the uses of it suggests unmistakably that it describes the moral content of actions. Because a moral action is one that is evaluated in respect to whether or not it is intended to cause harm to others, the term is overwhelmingly used to refer to those actions which, subject to a society's maxims and listing of harms, are judged to be illintentioned in those regards. First, then, according to that practical wisdom, a jajuok is a fear monger - he/she peddles fear unwarrantedly among members of the community by deliberately creating an atmosphere of general uncertainty and apprehension, in which people feel that sometimes their lives would be threatened in certain specific places. To successfully create such angst, a person with such intention either waylays and frightens passers-by at such a place a few times, or merely starts a false story claiming the occurrence of such incidences. Either way, word will spread within the community and even beyond that some unspecified danger lurks around such selected locations. Because a jajuok acts under the convenience of some kind of concealment such as darkness, the net result of his/her actions is the imposition of a mental curfew on a community whose members learn to restrict their movement by time or location for fear of an indeterminate source of danger. In contemporary global terms, concerns for security as exemplified in imposed checks at border crossing points, or other forms of travel related restrictions, speak to the effects of moral callousness in human intentions as is contained in the idea of juok, complete with the behavioral responses it provokes.

Still in local idioms, a person was also characterized as a jajuok if he/she deliberately did things that posed outright danger to a community, such as, for instance, polluting common resources like water or forests, either directly, or by compromising the conditions of their generation. A person who discards his/her trash or other types of

\footnotetext{
${ }^{14}$ See, for example, "The Concept of the Person in Luo Modes of Thought", in Brown, Lee M., ed., African Philosophy: New and Traditional Perspectives, New York, Oxford University Press, pp. 84106, and Themes in African Philosophy: Self and Community in a Changing World (forthcoming, Indiana University Press).
} 
pollutants into public waterways, or in water catchment areas, or who by any premeditated act inhibits public access thereto or to any other public resource, is considered a jajuok because by his/her deliberate actions, he/she causes fear and anxiety in people by exposing them to harm, whether actual or only potential. A jajuok acts in such mischievous ways as to interrupt the normal course of daily life of the general public. It does not matter to a jajuok that either by ignorance or by miscalculation, he/she too may become a victim of his/her own acts. Usually, however, he/she takes precaution to protect himself/herself and selected others from the intended effects of his/her actions which, in his/her estimation, are directed at other people. A jajuok is not a person at war, because his/her victim(s) is not defined, hence it is his/her moral motivation that becomes an issue. To shield himself/herself from accusations of responsibility in specific cases, a jajuok will give the impression that he/she too is, like everyone affected, just as much a victim of the deeds of which he/she is accused, so that the real culprits, the moral agents, must be others.

Translated into the language of global concern, the examples above point to difficult ethical problems at both personal and institutional levels. At a personal level, dangers posed by a jajuok to society can be compared to, say, the actions of serial stalkers and killers, or sexual offenders such as child molesters, rapists, and other predatory characters whose actions are unpredictable in terms of their timing, location, or victim, but who nonetheless manifest some undesirable pattern in their behaviour. At the institutional level, worries about a jajuok's breach of the availability or safety of public resources resonate with contemporary concerns about issues of environmental ethics, such as concerns about different acts that directly or indirectly lead to environmental degradation at all levels of the socio-political spectrum, that is, local, national, regional, and global. I have in mind the dominant moral figures in the village, and their constant reprimand of those who transgress the social space including the environment. That these individuals play an important role in shaping the community's moral character is not in dispute. Their actions become parameters along which we model our public institutions such as national environmental watchdogs which set standards for industrial activities.

The example of the idiom of juok above may first have arisen to address village morality, but it now addresses, by expanded application, new forms of personal and 
social responsibility anywhere and everywhere. The expansion of the fields of application allows for evocation and relation of principles of moral conduct to new matters such as the HIV/AIDS pandemic. The question, pertinent to all ethical concerns, can be framed thus: how am I to behave to ensure that I do the morally right thing in situations of HIV/AIDS?

The search for an answer to this question can start with the instructive lyrics of Ogwang' k'Okoth Lelo. Although he frames these lyrics in deeply localized modes of delivery, Ogwang' knows quite well, like many others around him, that the circumstances and contexts of moral responsibility and conduct do change and expand with one's sojourn into the wider world, and so the factors that inform our evaluation of such conduct should commensurately change to fit with the expanded scope of our moral awareness. ${ }^{15}$

\section{Conclusion}

The communal or relational character of African thought is not limited to the narrative, although the use of this mode goes a long way to demonstrate its ubiquity in African philosophical texts. Rather, as is evident in such expositions as Kwasi Wiredu's definition of the nature of truth, part of his broader philosophicoanthropological analysis of the idea of personhood, it is an axiomatic assumption on which significant differences between African and other modes of thought can and already do emerge. What is important to keep in mind is that the view that community is not an "entity" with fixed and reproducible characteristics does not compromise

\footnotetext{
${ }^{15}$ Ogwang'"s lyrics, sang in his ethnic Luo poetry and accompanied by the Nyatiti harp, his specialty, go somehow like this: "Ah! You make so much noise just to tell me that I will go to hell! And the reason, you tell me, is that I sing the praises of my people and make them happy? Your moral order sounds crooked indeed - that someone must be punished for celebrating with his people and for making them happy! So I knocked at the gates of their heaven and sang for their god, and he said he had no problems with son of Okoth. Then I proceeded to sing for their Satan who, in bewilderment about my skills in praising him, fell into a trance while I went into heaven. For, I fornicate not, steal not, and I am in most other ways socially and morally upright; in my people's eyes, I am a good man, and that is what matters. But you [addressing the group of Christians] must be hypocrites who live by the standards of foreign lands which you fathom not, but make noise to subvert what governs a good moral order and social system". Although he insists on being judged by the norms of his local moral code, Ogwang' appears in his lyrics to have been acutely aware of the universality of moral law and of the demands of moral responsibility.
} 
communitarianism as a principle of thought. Finally, as the inclusion of concepts from African cultural beliefs and knowledge systems in new publications of reference texts do bear witness, formerly restricted uses of local idioms are finally finding their way into the global lexicon, thereby enabling comparative analyses of ideas in ways that until now remained outside the circles of possibility.

\section{References}

Appiah, Kwame A. 1992. In My Father's House. New York: Oxford University Press --. 1996. "Cosmopolitan Patriots". Cohen, Joshua ed. For Love of Country: Debating the Limits of Patriotism, Martha C. Nussbaum with Respondents. Boston, Beacon Press.

--. 2005. The Ethics of Identity. Princeton, NJ: Princeton University Press.

--. 2006. Cosmopolitanism: Ethics in a World of Strangers. New York: W. W. Norton and Co. Publishers.

Aristotle. 1984. Poetics. Barnes, Jonathan ed. The Complete Works of Aristotle, the Revised Oxford Translation, Vol.2. Princeton: Princeton University Press.

Bachelard, Gaston. 1940. La philosophie du non: essai d'une philosophie du nouvel esprit scientifique. Presses Universitaires du France. (Eng. trans. G.C. Waterston, 1968. The Philosophy of No: A Philosophy of the New Scientific Mind, New York: Orion Press).

Bates, Robert, V.Y. Mudimbe, and Jean O'Barr, eds. 1993. Africa and the Disciplines: The Contributions of Research in Africa to the Social Sciences and Humanities. Chicago: University of Chicago Press.

Bidima, Jean-Godefroy, "De la traversée: raconter des experiences, partager le sens", in Rue Descartes, Vol. 36, Special edition, Philosophies africaines traversées des experiences, Juin 202, p. 7.

Césaire, Aimé. 1953. Discours sur le colonialisme. Paris: Présence Africaine.

Conteh-Morgan, John. Trans. 2002. The Struggle for Meaning. Athens, OH: Ohio University Center for International Studies.

Gyekye, Kwame. 1997. Tradition and Modernity: Philosophical Reflection on the African Experience. Philadelphia: Temple University Press.

Hallen, Barry. 2006. African Philosophy- African Philosophy: The Analytic Approach. Trenton, NJ and Asmara, Eritrea: African World Press.

Hountondji, Paulin J. 1983. African Philosophy: Myth and Reality. Bloomington: Indiana University Press.

--. 1997. Combats pour le sens, Cotonou, Benin, Editions du Flamboyant (English trans. The Struggle for Meaning, by John Conteh-Morgan, Athens, OH, Ohio University Center for International Studies, 2002).

Kokwaro, John. 1972. Luo-English Botanical Dictionary. Nairobi: East African Publishing House.

Masolo, D.A. 1994. African Philosophy in Search of Identity. Bloomington: Indiana University Press. 
--, 2004. "The Concept of the Person in Luo Modes of Thought". Brown, Lee M., ed., African Philosophy: New and Traditional Perspectives. New York: Oxford University Press.

--. forthcoming. Themes in African Philosophy: Self and Community in a Changing World, Indiana University Press).

Nzegwu, Nkiru U. 2006. Family Matters: Feminist Concepts in African Philosophy of Culture. Albany: State University of New York (SUNY) Press.

Ogot, Bethwell A. 1967. History of the Southern Luo, Vol. 1: Migration and Settlement 1500 - 1900. Nairobi: East African Publishing House.

Ogot, Grace. 1966. The Promised Land. Nairobi: Heinemann Educational Publishers.

Ricoeur, Paul. 1984. Time and Narrative, Vol. 1. Chicago: the University of Chicago Press.

Schopenhauer, Arthur. 2008. The World as Will and Presentation, Volume One. Aquila, Richard E. trans. New York: Pearson.

Sober, Elliot. 1995. Core Questions in Philosophy: A Text with Readings, $2^{\text {nd }}$ edition. Englewood Cliffs, NJ: Prentice Hall.

Tempels, Placid. 1945. La philosophie bantoue. Lovania: Elizabethville; Paris: Présence Africaine.

Wingo, Ajume H. 2004. "The Many Layered Aesthetics of African Art”. Wiredu, Kwasi ed. Companion to African Philosophy. Malden: Blackwell Publishing.

Wingo, Ajume. 1998. "African Art and the Aesthetics of Hiding and Revealing". British Journal of Aesthetics, Vol.38 No.1, July 1998, pp.277-291.

--. 2005. "The Joy of Living Together: Towards an Appreciation of Laughter". Journal of Political Philosophy, Vol.18 No.2, 2005.

Wiredu, Kwasi. 1980. Philosophy and an African Culture. London: Cambridge University Press.

--. 1996. Cultural Universals and Particulars. Bloomington: Indiana University Press.

Wiredu, Kwasi, ed. 2004. Companion to African Philosophy. Malden: Blackwell Publishing. 